\title{
Pemberdayaan Badan Usaha Milik Desa Melalui Kelompok Ekonomi Kewirausahaan Secara Partisipatif
}

\author{
Empowerment of Badan Usaha Milik Desa Through \\ Participatory Entrepreneurship Economic Groups
}

\author{
Ahmad Mustanir \\ STISIP Muhammadiyah Rappang \\ Sidenreng Rappang Regency, Indonesia \\ ahmadmustanir74@gmail.com
}

\begin{abstract}
Empat hal yang perlu kita fikirkan bersama dalam pengelolaan BUMDes. pertama, mengenali dan menggali potensi masing-masing desa dan mencari cara untuk mengelola potensi tersebut. Kedua, mendorong aliran dana CSR oleh swasta untuk mendukung permodalan BUMDes. Ketiga, mendorong munculnya inisiasi dari pemerintah desa. Keempat, mendorong peningkatan partisipasi masyarakat secara nyata. Dengan melakukan sedikitnya empat hal tersebut diharapkan ke depan setiap desa mampu memiliki BUMDes yang bisa turut menopang perekonomian masyarakat desa.
\end{abstract}

Keywords: Bumdes, CSR, Partisipasi Masyarakat, Pemberdayaan 


\section{BAB I \\ PENDAHULUAN}

\section{A. Latar Belakang}

Kegiatan pembangunan desa untuk memajukan perekonomian bangsa kini telah memiliki payung hukum yang mantap, yaitu Undang Undang No 6 Tahun 2014 Tentang Desa. Dalam implementasinya, Undang Undang Desa memiliki beberapa tujuan utama, yaitu: 1) Pengakuan dan status hukum pada sistem pemerintahan setingkat desa yang beragam di Indonesia; 2) Mendorong tradisi dan kebudayaan masyarakat; 3) Mendorong partisipasi warga dalam pemerintahan desanya; 4) Meningkatkan pelayanan untuk semua orang lewat lebih sanggupnya pemerintahan desa; 5) Mendorong pembangunan oleh warganya sendiri.

Pada perkembangannya, dikeluarkan regulasi yang mendukung UU Desa, yaitu PP No. 60/2014 tentang Dana Desa. Peraturan ini mengatur bahwa desa yang sekarang sudah bisa aktif turut membangun, perlu disokong dengan dana. Artinya, dana desa diadakan dengan dua cita-cita: pemerintah desa lebih bisa sanggup melayani kebutuhan warga, sekaligus warganya lebih aktif berinisiatif. Salah satu wadah untuk memajukan ekonomi desa adalah Badan Usaha Milik Desa atau BUMDes.

BUMDes pada dasarnya merupakan pilar kegiatan ekonomi di desa yang berfungsi sebagai lembaga sosial (social institution) dan komersial 
(commercial institution). BUMDes sebagai lembaga sosial harus berpihak kepada kepentingan masyarakat melalui kontribusinya dalam penyediaan pelayanan. Hal ini sesuai dengan tujuan pendirian sebuah Bumdes pada umumnya, yaitu: (1) Meningkatkan perekonomian desa, (2) Meningkatkan Pendapatan Asli Desa, (3) Meningkatkan pengelolaan potensi desa sesuai dengan kebutuhan masyarakat, dan (4) Menjadi tulang punggung pertumbuhan dan pemerataan ekonomi desa. BUMDes adalah badan usaha yang seluruh atau sebagian besar modalnya dimiliki oleh Desa melalui penyertaan secara langsung yang berasal dari kekayaan desa yang dipisahkan guna mengelola aset, jasa pelayanan dan usaha lainnya untuk sebesar-besarnya kesejahteraan masyarakat desa (pasal 1 UU No. 6 Tahun 2015).

Maksud dari kegiatan “Pemberdayaan BUMDes Melalui Kelompok Ekonomi Kewirausahaan Secara Partisipatif" adalah untuk mewujudkan kemandirian ekonomi desa melalui pengembangan kelembagaan dan pemberdayaan pengelolaan usaha ekonomi masyarakat yang dilaksanakan dengan keterlibatan masyarakat, pemerintah, dan swasta sehingga semua stake holder didesa berperan optimal dalam menumbuh kembangkan perekonomian desa (Mustanir \& Jusman, 2016a) (Mustanir, Yasin, Irwan, \& Rusdi, 2018) (Mustanir \& Jaya, 2016a) (Mustanir, Abadi, \& Nasri, 2016) (Mustanir \& Darmiah, 2016) (Mustanir \& Lubis, 2017a). 
Sedangkan tujuan Pemberdayaan BUMDes Melalui Kelompok Ekonomi Kewirausahaan Secara Partisipatif adalah:

1. Menguatkan kapasitas kelembagaan lainnya guna meningkatkan perekonomian desa serta memperkuat Pendapatan Asli Desa (PADes);

2. Meningkatkan kemampuan pengelolaan usaha Lembaga Ekonomi Desa yang berbasis pada pengolahan potensi desa sesuai dengan kebutuhan masyarakat dan peluang pasar;

3. Mengembangkan kemitraan usaha dengan unit/kelompok usaha yang ada di desa dan luar desa;

4. Mengembangkan modal usaha melalui penggalangan dana masyarakat maupun kerjasama dengan pihak ketiga;

5. Menjadi tulang punggung pertumbuhan dan pemerataan ekonomi perdesaan dalam rangka mewujudkan kesejahteraan sosial ekonomi masyarakat desa;

6. Memperkuat Pendapatan Asli Desa (PADes).

7. Membangun sinergitas antara pemerintah, masyarakat, dan swasta dalam rangka mengelola potensi dan meminimalisir permasalahan dalam pemberdayaan BUMDes.

8. Memperkuat sinergisme perguruan tinggi (PT) dengan stakehoder terkait dalam pembangunan desa.

9. Membentuk Desa Mangkawani sebagai desa mandiri. 
Sasaran Pemberdayaan BUMDes Melalui Kelompok Ekonomi Kewirausahaan Secara Partisipatif adalah Kegiatan Pemberdayaan BUMDes dilakukan pada Desa Mangkawani yang telah memiliki BUMDes dengan mengintegrasi atau konsolidasi lembaga ekonomi yang ada di desa maupun luar desa. Peluang dan tantangan dari BUMDes itu sendiri secara sederhana dapat dikatakan bahwa dalam pengembangan BUMDes penting untuk membangun sinergitas antara pemerintah, masyarakat, dan swasta. Ketiganya perlu bekerja dalam rangka mengelola potensi dan meminimalisir permasalahan pemberdayaan BUMDes (Akhmad, Mustanir, \& Ramadhan, 2018) (Razak, Dahong, Ahmad, Dema, \& Mustanir, 2018) (Mustanir \& Yasin, 2018) (Mustanir, Ahmad; Abadi, 2016) (Barisan, Ramadhan, \& Mustanir, 2017) (Mustanir \& Rusdi, 2019a).

Usulan kegiatan program-program dalam pembuatan program ini di harapkan lahir dari masyarakat sendiri melalui suatu proses penggalian akan kebutuhan masyarakat dan didasarkan pada masalah mereka serta penanganannya melalui potensi yang dimiliki oleh masyarakat. Proses ini dilakukan dengan metode perencanaan partisipatif melalui alat kaji PRA (Partisipatory Rural Appraisal) (Mustanir, 2016) (Mustanir, Justira, Sellang, \& Muchtar, 2018) (Mustanir, Ahmad; Barisan, Barisan; Hamid, 2017) (Mustanir \& Jaya, 2016b) (Mustanir \& Lubis, 2017b) (Mustanir, Ali, \& Yasin, 2018) (Mustanir \& Razak, 2017) (Mustanir \& Rusdi, 2019b) 
(Mustanir \& Jusman, 2016b) (Damis Dadda, Mustanir, Nilwana, \& Ahmad, 2019) (Mustanir \& Rusdi. Muhammad, 2019).

Dengan metode ini akan menumbuhkan cara pandang, pola pikir atau model pemberdayaan ekonomi BUMDes yang bersifat holistik, dan upayanya lebih diarahkan pada pemberdayaan BUMDes itu sendiri.

\section{B. Perumusan Masalah}

Berdasarkan dari hasil kajian latar belakang tersebut diatas, maka kami kami akan melakukan pengabdian masyarakat dengan maksud, untuk menjawab pertanyaan perumusan masalah. Adapun perumusan masalah yang dimaksud adalah Bagaimana memberdayakan BUMDes Melalui Kelompok Ekonomi Kewirausahaan Secara Partisipatif?

\section{Tinjauan Pustaka}

\section{BUMDes}

Kemunculan BUMDes dalam tata kelola pemerintahan desa dilatarbelakangi oleh adanya dorongan terhadap kemandirian dan otonomi di tingkat desa. Desa pada level terbawah diharapkan mampu meciptakan kemandirian guna meningkatkan taraf hidup masyarakat.

Berdasarkan Permendes PDTT nomor 4 tahun 2015 pasal 3 BUMDes didirikan dengan tujuan sebagai berikut :

a. Meningkatkan perekonomian Desa; 
b. Mengoptimalkan aset Desa agar bermanfaat untuk kesejahteraan Desa;

c. Meningkatkan usaha masyarakat dalam pengelolaan potensi ekonomi Desa;

d. Mengembangkan rencana kerja sama usaha antar desa dan/atau dengan pihak ketiga;

e. Menciptakan peluang dan jaringan pasar yang mendukung kebutuhan layanan umum warga;

f. Membuka lapangan kerja;

g. Meningkatkan kesejahteraan masyarakat melalui perbaikan pelayanan umum, pertumbuhan dan pemerataan ekonomi Desa; dan

h. Meningkatkan pendapatan masyarakat Desa dan Pendapatan Asli Desa.

Sehingga untuk mendukung berjalannya tujuan tersebut pemerintah menujukkan keseriusannya dalam mengelola BUMDes dengan mengeluarkan beberapa peraturan tentang BUMDes, diantaranya sebagai berikut:

Pertama, dalam UU nomor 23 tahun 2014 yakni: "desa dapat mendirikan badan usaha milik desa yang sesuai dengan kebutuhan dan potensi desa". Kedua, diatur dalam PP nomor 72 tahun 2005 tentang Desa pasal 78 sampai dengan 81 . Ketiga, Peraturan Menteri Dalam Negeri nomor 39 
tahun 2010 tentang Badan Usaha Milik Desa. Keempat, Undang-Undang nomor 6 tahun 2014 tentang Desa. Kelima, Permendesa nomor 4 tahun 2015 tentang Pendirian Pengurusan Dan Pengelolaan dan Pembubaran Badan Usaha Milik Desa. Dalam peraturan tersebut kurang lebih diatur dengan cukup jelas terkait dengan pendirian BUMDes, pengelolaan, permodalan, dan manfaat BUMDes yang diperuntukkan sepenuhnya bagi masyarakat desa.

Meskipun berbentuk badan usaha namun BUMDes memiliki perbedaan dengan badan usaha pada umumnya. Dalam Buku Panduan Pendirian Pengeloaan BUMDes (2007) dijelaskan bahwa terdapat sedikitnya tujuh ciri utama yang membedakan BUMDes dengan jenis usaha yang laiannya. Pertama, BUMDes bukan milik perseorangan atau individu, namun badan usaha ini dimiliki oleh desa dan dikelola secara bersama. Kedua, modal usaha bersumber dari desa sebesar 51\% dan sisanya bersumber dari masyarakat dan atau dukungan dari sponsor melalui sistem penyertaan modal. Ketiga, memperhatikan budaya lokal. Keempat, BUMDes menyesuaikan dengan potensi yang dimiliki oleh desa. Kelima, keuntungan sepenuhnya diperuntukkan untuk pengelola dan masyarakat desa. Keenam, difasilitasi oleh pemerintah provinsi, kabupaten, kota, dan pemerintah desa. Ketujuh, pengawasan dilakukan secara bersama oleh pemerintah desa dan Badan Permusyawaratan Desa (BPD). 


\section{Partisipasi dan Partisipasi Masyarakat}

Totok Mardikanto dan Poerwoko Soebiato dalam Ahmad Mustanir (2017: 316-317). Mengemukakan tentang lingkup partisipasi dengan bertolak pada urutan proses perencanaan pembangunan, maka secara rinci jenis partisipasi dalam pembangunan sebagai berikut : 1) Partisipasi dalam pengambilan keputusan, 2) Partisipasi dalam pelaksanaan kegiatan, 3) Partisipasi dalam pemantauan dan evaluasi pembangunan, 4) Partisipasi dalam pemanfaatan hasil-hasil pembangunan.

Menurut Suharto dalam Ahmad Mustanir (2017) Masyarakat adalah sekelompok orang yang memiliki perasaan sama, menyatu satu sama lain karena mereka saling berbagi identitas, kepentingankepentingan yang sama, perasaan memiliki, dan biasanya satu tempat yang sama.

Adisasmita dalam Ahmad Mustanir (2017:356-358) mengemukakan bahwa Partisipasi Masyarakat adalah pemberdayaan masyarakat, peran sertanya dalam kegiatan penyusunan perencanaan implementasi program/proyek pembangunan, dan merupakan aktualisasi dan kesediaan dan kemauan masyarakat untuk berkorban dan berkontribusi terhadap implementasi Program Pembangunan. Partisipasi masyarakat menurut Isbandi dalam Ahmad Mustanir (2017 : 2-3) adalah keikutsertaan masyarakat dalam proses pengidentifikasian masalah dan potensi yang ada di masyarakat, pemilihan dan pengambilan keputusan tentang 
alternatif solusi untuk menangani masalah, pelaksanaan upaya mengatasi masalah, dan keterlibatan masyarakat dalam proses mengevaluasi perubahan yang terjadi.

\section{Pemetaan Swadaya dan Participatory Rural Appraisal (PRA)}

Totok Mardikanto dan Poerwoko Soebiato dalam Ahmad Mustanir (2017: 82-84). Mengemukakan tentang lingkup partisipasi dengan bertolak pada urutan proses perencanaan pembangunan, maka secara rinci jenis

Metode dan teknik yang dikembangkan untuk Pemetaan Swadaya merupakan metode yang lebih menekankan pada proses diskusi masyarakat. Alat kajian (tools) yang dikembangkan adalah alat untuk mengajak masyarakat terlibat dalam proses penggalian informasi, analisa dan perumusan masalah/kebutuhan/program, sehingga melalui proses tersebut sebetulnya masyarakat yang terlibat menjadi peneliti bagi dirinya dan kehidupan lingkungannya sendiri (Konsultan Manajemen Wilayah - VI P2KP II: 2004)

Dalam Pemetaan Swadaya masalah-masalah yang menjadi hambatan dicari dan digali lebih dalam melalui proses diskusi, survey, dan teknik kajian lainnya sehingga didapatkan gambaran nyata kebutuhan masyarakat yang harus diupayakan pemenuhannya (pemecahan masalah) (KMW PNPM P2KP). 
Chambers memperkenalkan metode PRA sebagai alternative bagi para praktisi pembangunan yang memerlukan sebuah metodologi 'penelitian' yang bisa membantu mereka memahami masyarakat secara cepat, dengan informasi aktual, dan biaya murah, serta bisa mengajak masyarakat sebagai pelaku penelitian itu sendiri (Chambers, 1992).

\section{Manfaat Kegiatan}

Program pengabdian masyarakat ini memiliki 3 (tiga) manfaat, yaitu;

a. Menjadi sarana bagi dosen untuk melaksanakan salah satu Tri Dharma Perguruan Tinggi berupa pengabdian kepada masyarakat.

b. Mendapatkan pengalaman dan kemanfaatan bagi mahasiswa yang merupakan salah satu unsur perguruan tinggi yang memiliki kewajiban tridharma sama seperti dosen.

c. Manfaat ke masyarakat sasaran. Manfaat ini antara lain :

1) Menguatkan kapasitas dan meningkatkan kemampuan pengelolaan usaha Lembaga Ekonomi Desa yang berbasis pada pengolahan potensi desa sesuai dengan kebutuhan masyarakat dan peluang pasar.

2) Akan terjadi pengembangan kemitraan usaha dan pemberdayaannya.

3) Akan terbangun sinergitas antara pemerintah, masyarakat, dan 
swasta dalam rangka mengelola potensi dan meminimalisir permasalahan dalam pemberdayaan BUMDes.

\section{E. Sasaran}

Sasaran pelaksanaan program ini adalah BUMDes dan Kelompok Ekonomi Kewirausahaan Desa Mangkawani.

\section{F. Target Luaran}

Target luaran Pemberdayaan BUMDes Melalui Kelompok Ekonomi Kewirausahaan Secara Partisipatif yang di harapkan adalah tersusunnya sebuah program perencanaan dan pelaksanaan untuk mewujudkan kemandirian ekonomi desa melalui pengembangan kelembagaan dan pemberdayaan pengelolaan usaha ekonomi masyarakat secara partisipatif yang dilaksanakan dengan keterlibatan masyarakat, pemerintah, dan swasta sehingga semua stake holder didesa berperan optimal dalam menumbuh kembangkan perekonomian desa.

Selain itu target luaran yang lain adalah terpublikasinya hasil pengabdian dalam proceeding internasional.

\section{G. Metode Penerapan}

Metode dalam penerapan program ini disusun secara sistematis, yang bertujuan untuk memaksimalkan jalannya program, dengan 
beberapa tahapan pelaksanaan :

1. Pelatihan mahasiswa sebagai fasilitator pendamping

Pelatihan yang digunakan adalah :

a) Pelatihan Dasar

Lebih bersifat pelatihan penyadaran (awareness training) dengan penekanan re-orientasi pola pikir dan sikap melalui pembangunan manusia (pemulihan nilai-nilai luhur) dan pengenalan dan pemahaman dasar-dasar yang nantinya akan melibatkan masyarakat sasaran sebagai pelaku utama melalui proses pemberdayaan.

b) Pelatihan Siklus Program

Penekanan pada penyadaran dan pemahaman terhadap perlunya tiap tahapan siklus (apa, mengapa) dan keterkaitan setiap siklus terhadap seluruh proses pembelajaran.

c) Pelatihan Keterampilan

Menekankan pengembangan ketrampilan (skill training) yang berorientasi kepada pemecahan persoalan yang dihadapi di lapangan serta menerapkan metode dan teknik-teknik yang dibutuhkan untuk bekerjasama dengan masyarakat yang mampu meningkatkan kemampuan masyarakat desa utamanya relawan dalam menjalankan program dari, oleh dan untuk masyarakat secara partisipatif (PRA). 
Ketiga pelatihan ini di jalankan dengan metode pelatihan intensif berupa bimbingan (coaching) dan penjelasan (briefing) melalui Focus Group Discussion (FGD).

2. Pelaksanaan sosialisasi program tingkat desa dan Pelaksanaan sosialisasi tingkat Dusun

Metode dalam pelaksanaan sosialisasi semua tingkatan ini adalah dengan mengumpulkan warga masyarakat di masing-masing wilayah dalam sebuah musyawarah warga dan diberikan sosialisasi pencerahan maksud, tujuan dan sasaran program. Dalam sosialisasi tersebut akan disebarkan leaflet. Perlunya metode ini dilaksanakan di tingkatan wilayah agar warga tidak memiliki hambatan psikologi untuk menyampaikan pendapatnya jika harus dilaksanakan langsung di tingkatan desa.

3. Pelatihan relawan masyarakat

Seluruh model dan metode yang dilaksanakan dalam pelatihan fasilitator akan dilakukan dalam pelatihan relawan masyarakat. Ini didasarkan pemikiran bahwa relawan lah yang akan melanjutkan program ini secara berkelanjutan di tahun-tahun mendatang.

4. Musyawarah pemetaan swadaya yang berbasis dusun.

Dijalankan dengan sistem pembelajaran orang dewasa yang menekankan musyawarah melalui FGD yang bersifat informal dengan suasana santai dan penerapan metode Participatory Rural Appraisal 
(PRA). Ini didasarkan pemikiran jika masyarakat dibawa dalam 'suasana mereka' maka akan lebih mudah menggali aspirasi mereka secara lebih baik/partisipatif dan mereka akan merasa memiliki dan bertanggung jawab terhadap keberlanjutan program nantinya.

5. Lokakarya perencanaan tingkat dusun dan Lokakarya perencanaan tingkat desa

Metode yang dijalankan melalui musyawarah FGD. Metode ini diharapkan akan melibatkan partisipasi warga dan kesepahaman warga akan prioritas program sesuai kebutuhan dan kemendesakannya.

6. Penyusunan dokumen perencanaan pemberdayaan masyarakat berbasis ekonomi kewirausahaan

Metode yang dilakukan dengan cara rapat dan diskusi. Metode ini dipilih agar hasil lokakarya dapat disusun secara teratur dan sistematis.

7. Penguatan kelembagaan BUMDes (restrukturirasi jika diperlukan)

Metode penguatan kelembagaan dilakukan dengan melakukan restrukturisasi kepengurusan. Bisa dengan merekomendasikan orangorang yang dipercayai oleh warga sesuai kriteria dalam pemetaan swadaya untuk duduk didalam kepengurusan tersebut.

8. Pelatihan pengelolaan keuangan BUMDes

Metodenya dengan pemberian pelatihan dasar yang lebih bersifat pelatihan penyadaran (awareness training) dengan penekanan re- 
orientasi pola pikir dan sikap melalui pembangunan manusia (pemulihan nilai-nilai luhur) dan pengenalan dan pemahaman dasardasar yang nantinya akan melibatkan masyarakat sasaran sebagai pelaku utama melalui proses pemberdayaan. Metode ini didasarkan bahwa pelatihan yang dilaksanakan berorientasi kepada pengembangan pemahaman, penumbuhan sikap dan peningkatan kemampuan (Mengerti, Mau dan Mampu) yang sesuai dengan peran pelaku. Selain itu dengan memberikan skill dalam pengelolaan keuangan BUMDes dengan mengundang narasumber yang berkompeten dibidangnya.

9. Pelatihan kelompok-kelompok usaha ekonomi kewirausahaan/KSM

Metodenya dengan memfasilitasi penggerakan masyarakat untuk berhimpun secara swadaya, fasilitasi pra kelompok swadaya, dan akhirnya mengesahkan adanya kelompok swadaya masyarakat

10.Menjalin kemitraan usaha dengan unit/kelompok usaha yang lainnya Metode yang dilakukan dengan memfasilitasi terjalinnya kemitraan tersebut dengan mencari usaha-usaha/chaneling didesa.

11.Membangun sinergitas antara pemerintah, masyarakat, dan swasta dalam rangka mengelola potensi dan meminimalisir permasalahan dalam pemberdayaan BUMDes.

Metodenya dengan memfasilitasi dalam menjalin sinergitas tersebut khususnya menjalin komunikasi diantara ketiga stakeholder. 


\section{H. Keterkaitan}

Keterkaitan yang dimaksud dalam program ini yaitu keterkaitan yang terbangun antar setiap kelompok ekonomi kewirausahaan yang terlibat dengan BUMDes pada program pengabdian masyarakat serta sinergitas antara pemerintah, masyarakat, dan swasta.

\section{Jadwal Pelaksanaan}

Tabel. 1

\begin{tabular}{|c|c|c|c|c|c|c|c|c|c|c|c|c|c|}
\hline \multirow{2}{*}{ No } & \multirow{2}{*}{ Kegiatan } & \multicolumn{12}{|c|}{ Bulan } \\
\hline & & 11 & 12 & 1 & 2 & 3 & 4 & 5 & 7 & 8 & 8 & 9 & 10 \\
\hline \multirow{5}{*}{1} & Persiapan pengabdian & & & & & & & & & & & & \\
\hline & Pengajuan UP & & & & & & & & & & & & \\
\hline & Seleksi UP & & & & & & & & & & & & \\
\hline & Keputusan Pengabdian & & & & & & & & & & & & \\
\hline & Penandatangan Kontrak & & & & & & & & & & & & \\
\hline \multirow{6}{*}{2} & Pelaksanaan Pengabdian & & & & & & & & & & & & \\
\hline & Pelaksanaan Pengabdian & & & & & & & & & & & & \\
\hline & Laporan Kemajuan & & & & & & & & & & & & \\
\hline & Pemantauan Pelaksanaan & & & & & & & & & & & & \\
\hline & Pengabdian & & & & & & & & & & & & \\
\hline & Laporan Hasil Pengabdian & & & & & & & & & & & & \\
\hline
\end{tabular}




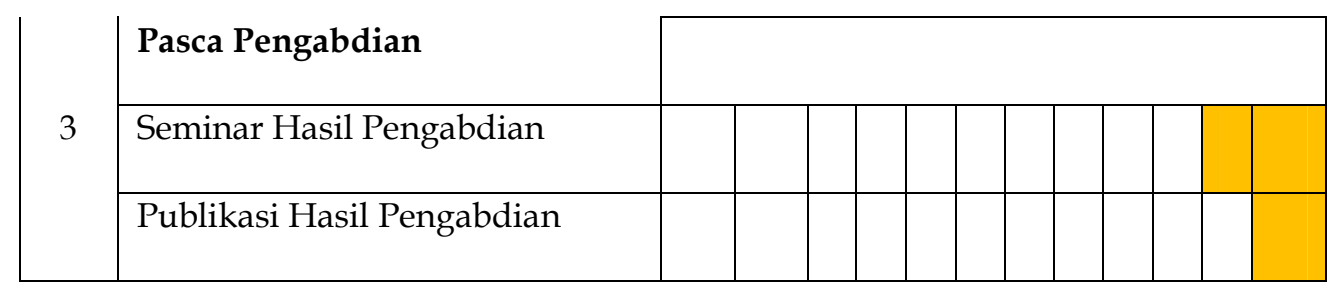




\section{BAB II}

\section{GAMBARAN LOKASI}

\section{A. Kondisi Geografis}

Desa Mangkawani terletak 35 KM dari Ibukota Kabupaten Enrekang, atau 3,5 Km dari Ibukota Kecamatan Mangkawani dengan luas wilayah seluas $\pm 12.50 \mathrm{KM}^{2}$, dengan batas-batas sebagai berikut :

1) Sebelah Utara berbatasan dengan Desa Puncak Harapan

2) Sebelah Selatan berbatasan dengan Kelurahan Bangkala

3) Sebelah Timur berbatasan dengan Desa Tuncung

4) Sebelah Barat berbatasan dengan Desa Botto Mallangga

Keadaan iklim di Desa Mangkawani terdiri dari : Musim Hujan, kemarau dan musim pancaroba. Dimana musim hujan biasanya terjadi antara Bulan November s/d Februari, musim kemarau antara bulan Juli s/d Oktober, sedangkan musin pancaroba antara bulan Maret s/d Juni.

\section{B. Kondisi Demografis}

1) Jumlah Penduduk

Jumlah Penduduk/KK, Jiwa, RTM = 219 Jiwa/85 KK, RTSM 188 Jiwa/47 KK = , Non RTM = 1,026 Jiwa/217 KK 
Tabel 2. Jumlah Penduduk Sesuai dengan Dusun/Lingkungan

\begin{tabular}{|c|l|c|c|c|c|}
\hline \multirow{2}{*}{ NO } & \multirow{2}{*}{ NAMA DUSUN } & \multicolumn{3}{|c|}{ JUMLAH JIWA } & \multirow{2}{*}{\begin{tabular}{c} 
KEPALA \\
\cline { 3 - 5 }
\end{tabular}} \\
\cline { 3 - 5 } 2. & Dusun Sabbang & 247 & 264 & 511 & 114 \\
3. & Dusun Uru & 209 & 219 & 428 & 106 \\
4. & Dusun Batuapi.I & 138 & 136 & 274 & 63 \\
\hline & Dusun Batuapi.II & 104 & 120 & 224 & 56 \\
\hline
\end{tabular}

2) Tingkat Pendidikan

Tabel 3. Tingkat Pendidikan

\begin{tabular}{|c|l|c|}
\hline NO & \multicolumn{1}{|c|}{ TINGKAT PENDIDIKAN } & JUMLAH \\
\hline 1 & TIDAK/BELUM SEKOLAH & 317 \\
\hline 2 & TIDAK/BELUM TAMAT SD/SEDERAJAT & 229 \\
\hline 3 & TAMAT SD SEDERAJAT & 367 \\
\hline 4 & TAMAT SLTP/SEDERAJAT & 270 \\
\hline 5 & TAMAT SLTA/SEDERAJAT & 202 \\
\hline 6 & DIPLOMA/STRATA & 49 \\
\hline
\end{tabular}

3) Mata Pencaharian

Tabel 4. Mata Pencaharian

\begin{tabular}{|c|l|c|}
\hline NO & \multicolumn{1}{|c|}{ JENIS PEKERJAAN } & JUMLAH \\
\hline 1 & BELUM / TIDAK BEKERJA & 360 \\
\hline 2 & MENGURUS RUMAH TANGGA & 348 \\
\hline
\end{tabular}




\begin{tabular}{|c|c|c|}
\hline NO & JENIS PEKERJAAN & JUMLAH \\
\hline 3 & PELAJAR/MAHASISWA & 346 \\
\hline 4 & PETANI/PEKEBUN & 229 \\
\hline 5 & PEGAWAI NEGERI SIPIL & 11 \\
\hline 6 & GURU & 6 \\
\hline 7 & BURUH & 20 \\
\hline 8 & WIRASWASTA & 78 \\
\hline 9 & PETERNAK & 1 \\
\hline 10 & KARYAWAN HONORER/SWASTA & 14 \\
\hline 11 & SOPIR & 9 \\
\hline 12 & MEKANIK & 2 \\
\hline 13 & KEPALA DESA & 1 \\
\hline 14 & PERANGKAT DESA & 2 \\
\hline 15 & PENSIUNAN/PURNABHAKTI & 2 \\
\hline 16 & TUKANG LAS/KAYU & 2 \\
\hline 17 & TNI & 1 \\
\hline 18 & BIDAN & 1 \\
\hline 19 & PERDAGANGAN & 1 \\
\hline
\end{tabular}

\section{Potensi}

1) Potensi Dalam Pola Penggunaan Tanah

Pola penggunaan tanah umumnya digunakan sebagai lahan perumahan, persawahan, peternakan, perikanan(kolam tanah), perkebunan (sayuran, jagung, kakao, rambutan, enau, pohon buah naga, lada, cengkeh, mangga, kelapa, dll.) dengan panen musiman/tahunan. 
2) Potensi Kepemilikan Ternak

Tabel 5. Kepemilikan Ternak

\begin{tabular}{|c|c|c|c|c|c|}
\hline Ayam/Itik & Sapi & Kerbau & Kuda & Kambing & Lain-lain \\
\hline 56.750 & 247 & 8 & - & 13 & - \\
\hline
\end{tabular}

3) Potensi Sarana dan Prasarana Desa

Tabel 6. Sarana / Prasarana Desa

\begin{tabular}{|c|c|c|c|c|c|c|c|}
\hline Kantor & Kantor & Balai & Jalan & Jalan & & \multicolumn{2}{|c|}{ Sekolah } \\
\hline BPD & Desa & Desa & Kabupaten & Desa & IViasjex & (SD & TK \\
\hline - & $1 \mathrm{Bh}$ & $1 \mathrm{Bh}$ & $5 \mathrm{Km}$ & $14 \mathrm{Km}$ & 3 unit & $1 \mathrm{Bh}$ & $1 \mathrm{Bh}$ \\
\hline
\end{tabular}




\section{BAB III}

\section{GAMBARAN KEGIATAN}

\section{A. Mekanisme Pelaksanaan Kegiatan}

1. Pelatihan mahasiswa sebagai fasilitator pendamping

Pelatihan mahasiswa sebagai fasilitator pendamping dilakukan oleh dosen pendamping di desa tersebut. Pelatihan mahasiswa sebagai fasilitator pendamping ini sangat penting mengingat fasilitator nantinya sebagai ujung tombak keberhasilan pelaksanaan program di desa. Peran mahasiswa sebagai fasilitator pendamping dalam memberikan dukungan terhadap pencapaian kinerja program mempunyai andil yang besar karena mereka yang akan menjadi konsultan pendamping bagi warga. Oleh karena itu, pelaksanaan fasilitator ini dilakukan secara fokus dan terarah, sehingga mahasiswa dapat benar-benar mengimpelementasikan sasaran-sasaran yang telah ditargetkan.

Beberapa hal yang menjadi fokus dalam pelatihan fasilitator adalah:

a. Penjelasan prinsip dan mekanisme tahapan program

b. Strategi memobilisasi masyarakat dan pemberdayaan

c. Praktek dan simulasi penggunaan metode PRA (Participatory Rural Appraisal) dalam menggali permasalahan dan potensi yang dimiliki masyarakat secara partisipatif untuk mengetahui permasalahan, potensi dan usulan program usaha ekonomi kewirausahaannya.

d. Penyusunan laporan 
Materi-materi yang diterima oleh mahasiswa fasilitator pendamping tersebut juga harus disalurkan kepada relawan masyarakat sebagai pengelola kegiatan di desa.

2. Pelaksanaan sosialisasi program tingkat desa

Sosialisasi kegiatan dilaksanakan untuk menyebarluaskan konsep, mekanisme penyelenggaraan program serta menyatukan persepsi dalam pelaksanaan kegiatan Pemberdayaan BUMDes Melalui Kelompok Ekonomi Kewirausahaan Secara Partisipatif. Sosialisasi ini dilaksanakan secara berjenjang. Sosialisasi di tingkat desa dipersiapkan dan dilaksanakan oleh Kepala Desa dengan didampingi dosen dan mahasiswa fasilitator pendamping. Sosialisasi dilaksanakan dengan mengundang perangkat desa terkait, aparat pemerintah kecamatan. Sosialisasi juga mengundang Tokoh Masyarakat, Tokoh Agama, dan Kelompok/Organisasi Masyarakat, para kepala dusun/RW/RT serta anggota masyarakat secara luas. Materi sosialisasi juga membahas tentang kesiapan masyarakat untuk melaksanakan mekanisme dan prinsip-prinsip program. Keputusan kesiapan masyarakat ini juga merupakan perwujudan apresiasi masyarakat dan upaya membangun peran masyarakat untuk ikut dalam setiap proses tahapan pelaksanaan program. Peran dosen dan mahasiswa fasilitator pendamping adalah memfasilitasi pelaksanaan sosialisasi, menyiapkan alat dan bahan, dan menjadi narasumber utama. 
3. Pelaksanaan sosialisasi tingkat Dusun

Sosialisasi kegiatan tingkat dusun ini dilaksanakan juga untuk lebih menyebarluaskan konsep, mekanisme penyelenggaraan program serta menyatukan persepsi dalam pelaksanaan kegiatan program Pemberdayaan BUMDes Melalui Kelompok Ekonomi Kewirausahaan Secara Partisipatif sampai ke dusun-dusun. Sosialisasi tingkat dusun dilaksanakan sebanyak 4 (empat) kali. Sosialisasi di tingkat dusun dipersiapkan oleh Kepala Dusun dengan didampingi dosen dan mahasiswa fasilitator pendamping. Sosialisasi dilaksanakan dengan mengundang perangkat desa terkait, serta anggota masyarakat secara luas di dusun bersangkutan. Peran dosen dan mahasiswa fasilitator pendamping adalah memfasilitasi pelaksanaan sosialisasi, menyiapkan alat dan bahan, dan menjadi narasumber.

4. Pelatihan relawan masyarakat

Pelatihan relawan dimaksudkan untuk memperkuat dan mengembangkan kapasitas relawan/kader-kader masyarakat sebagai agen pemberdayaan masyarakat yang nantinya diharapkan menjalankan program dan menjaga keberlanjutan program dimasa depan. Diharapkan juga dapat mengembangkan kerjasama antara fasilitator dengan relawan. Peran dosen dan mahasiswa fasilitator pendamping adalah memfasilitasi pelatihan, menyiapkan alat dan bahan pelatihan, dan menjadi narasumber. 
5. Musyawarah pemetaan swadaya yang berbasis Dusun Musyawarah ini menggunakan metode PRA (Participatory Rural Appraisal) untuk memfasilitasi masyarakat berdiskusi dan mengkaji mengenai keadaan wilayah desa beserta lingkungannya terkait kebutuhan program Pemberdayaan BUMDes Melalui Kelompok Ekonomi Kewirausahaan, perubahan-perubahan yang terjadi di lingkungannya, serta sebab dan akibat dari perubahan tersebut.

Manfaat dari pemetaan ini dapat menimbulkan partisipasi yang sangat baik karena kegiatan ini cukup mudah dan mengasyikan dilakukan oleh berbagai lapisan masyarakat. Dengan demikian, kegiatan pemetaan ini juga merupakan bagian dari proses penyadaran bagi masyarakat akan lingkungannya. Selain itu, informasi yang didapat dalam pemetaan dapat menjadi dasar dari pemilihan dan penggalian informasi dengan teknik-teknik yang lainnya. Pemetaan dijadikan dasar perencanaan dan evaluasi program di waktu-waktu mendatang. Pemetaan swadaya yang berbasis RW dilaksanakan sebanyak 4 (empat) kali sesuai jumlah dusun yang ada di Desa Mangkawani. Peran dosen dan mahasiswa fasilitator pendamping adalah memfasilitasi dengan mendampingi dan menjalankan musyawarah melalui penggunaan metode PRA beserta teknik-tekniknya di tingkat dusun. Menyiapkan alat dan bahan, dan menjadi narasumber musyawarah. 
6. Lokakarya perencanaan tingkat Dusun

Lokakarya ini dilakukan agar program dan kegiatan sinkron dengan visi jangka panjang program diantaranya sebagai berikut :

a) Mengetahui kondisi riil wilayah baik dari persoalannya maupun potensi dan hambatannya hasil pemetaan swadaya.

b) Mengambarkan kondisi ideal yang diharapkan dari kondisi riil, sehingga menghasilkan upaya-upaya yang akan dilakukan

c) Merumuskan tujuan-tujuan yang ingin dicapai dalam setiap program yang akan dilakukan.

d) Merumuskan program-program yang efektif untuk dijalankan.

e) Menentukan prioritas kegiatan yang akan dilaksanakan di tahun pertama.

f) Menentukan target yang ingin dicapai dalam setiap tahunnya,

g) Melengkapi data rencana tahunan berdasarkan data dan informasi hasil pemetaan swadaya.

h) Mengetahui orang-orang yang dipercayai oleh warga sesuai kriteria dalam pemetaan swadaya untuk mengelola program di tingkat Dusun nya jika dilakukan restrukturisasi BUMDes

Peran dosen dan mahasiswa fasilitator pendamping adalah memfasilitasi dengan mendampingi dan menjalankan lokakarya, menyiapkan alat dan bahan, dan menjadi narasumber lokakarya. 
7. Lokakarya perencanaan tingkat desa

Seperti halnya pelaksanaan lokakarya tingkat dusun. Pelaksanaan lokakarya tingkat desa juga melakukan hal yang sama, tetapi penetapannya berdasarkan hasil kesepakatan di tingkat desa. Dalam lokakarya ini diharapkan lahir kebutuhan akan program-program secara partisipatif yang dapat menyelesaikan segala macam permasalahan pemberdayaan BUMDes berbasis kelompok ekonomi kewirausahaan partisipatif dan upaya revitalisasi penguatan peran BUMDes.

Peran dosen dan mahasiswa fasilitator pendamping adalah memfasilitasi dengan mendampingi dan menjalankan lokakarya, menyiapkan alat dan bahan, dan menjadi narasumber lokakarya

8. Penyusunan dokumen perencanaan yang berisikan program-program kegiatan Pemberdayaan BUMDes berbasis kelompok ekonomi kewirausahaan partisipatif dan upaya revitalisasi penguatan peran BUMDes.

Kegiatan ini bermaksud untuk menyusun lebih rapi dan sistematis hasil-hasil lokakarya perencanaan tingkat desa yang masih terfragmentasi saat lokakarya. Kegiatan ini diperlukan agar program yang sudah di tetapkan, dapat dengan mudah untuk di inventarisir dan tersusun program rencana tahunan berdasarkan data dan informasi hasil pemetaan swadaya. Kegiatan ini melibatkan warga 
yang duduk dalam kepengurusan BUMDes atau mereka yang direkomendasikan warga yang di anggap berkompeten dan dipercayai sesuai dengan kriteria dalam pemetaan swadaya untuk duduk dalam kepengurusan jika dilakukan restrukturisasi kepengurusan. Kegiatan ini dilakukan bersama dengan dosen dan mahasiswa fasilitator pendamping.

Dosen dan mahasiswa fasilitator pendamping akan memfasilitasi dengan mendampingi dan membimbimbing penyusunan program, menyiapkan alat dan bahan.

9. Penguatan kelembagaan BUMDes (restrukturirasi jika diperlukan) Penguatan kelembagaan BUMDes dilakukan dengan merevitalisasi kepengurusan, bahkan jika diperlukan akan dilakukan restrukturisasi kepengurusan dengan merekomendasikan beberapa warga yang di anggap berkompeten dan dipercayai sesuai dengan kriteria dalam pemetaan swadaya untuk duduk dalam kepengurusan.

Peran dosen dan mahasiswa fasilitator pendamping akan memfasilitasi dengan mendampingi dan membimbimbing penguatan kelembagaan, memfungsikan kerja dan kinerja anggota BUMDes dalam pelaksanaan program-program secara partisipatif yang dapat menyelesaikan segala macam permasalahan Pemberdayaan BUMDes Melalui Kelompok Ekonomi Kewirausahaan Secara Partisipatif. 
10.Pelatihan pengelolaan keuangan BUMDes

Inti dari kegiatan pelatihan adalah untuk meningkatkan pengetahuan, memperbaiki sikap dan meningkatkan kemampuan anggota BUMDes, oleh karena itu materi atau topik pelatihan yang dikembangkan didasarkan pada kompetensi yang harus dimiliki oleh jajaran pelaku di dalam menjalankan tugas dan fungsinya. Dengan latar belakang pengalaman pelaku yang berbeda, tingkat pengetahuan dan pemahaman pelaku, akan berbeda pula pelatihan yang dikembangkan dan akan didasarkan pada kebutuhan serta pemecahan masalah dalam melaksanakan tugas di lapangan secara mandiri.

Peran dosen dan mahasiswa fasilitator pendamping akan memfasilitasi pelaksanaan pelatihan, menyiapkan alat dan bahan, menjadi narasumber utama. Selain itu akan mengundang pihak ketiga dalam memberikan materi yang berkompeten dalam bidang pengelolaan keuangan.

11.Pelatihan kelompok-kelompok usaha ekonomi kewirausahaan/KSM.

KSM merupakan kumpulan orang yang menghimpun diri secara sukarela dalam kelompok dikarenakan adanya ikatan pemersatu yaitu kepentingan dan kebutuhan yang sama sehingga dalam kelompok tersebut memiliki kesamaan tujuan yang ingin dicapai bersama khususnya dalam bidang usaha ekonomi kreatif partisipatif. KSM ini merupakan kelompok pemberdayaan. Bisa dikatakan KSM menjadi 
wadah bagi tumbuhnya rasa percaya diri, semangat kemandirian, saling kepercayaan sosial, rasa kebersamaan dan lain-lain. Pembentukan KSM ini penting karena dalam KSM mempunyai tujuan pembentukan :

a) Tumbuh dan berkembangnya kapital sosial di masyarakat.

b) Masyarakat yang makin dinamis dalam mengembangkan nilai-nilai kemanusiaan serta kemasyarakatan.

c) Terjadinya proses pembelajaran, tumbuh rasa saling asih, asah dan asuh antar sesama anggota

d) Anggota melakukan konsolidasi untuk menggalang kekuatan bersama khususnya dibidang ekonomi

e) Berfungsinya pelembagaan tanggung renteng, gerakan keswadayaan modal, kepercayaan bersama

Peran dosen dan mahasiswa fasilitator pendamping akan memfasilitasi penggerakan masyarakat untuk berhimpun secara swadaya, fasilitasi pra kelompok swadaya, pengesahan adanya kelompok swadaya masyarakat, Pembahasan permasalahan dan penyusunan program KSM, perintisan perwujudan eksistensi KSM

12. Menjalin kemitraan usaha dengan unit/kelompok usaha yang lainnya. Kegiatan ini dilakukan dan penting untuk mewujudkan peran dan fungsi dalam pembentukan KSM khususnya sebagai alat dalam proses perubahan sosial dan proses pembelajaran yang terjadi dalam KSM 
diarahkan untuk mendorong terjadinya perubahan nilai-nilai, membiasakan praktek nilai-nilai baru, cara pandang dan cara kerja baru dan melembagakannya dalam praktek kehidupan sehari-hari untuk mengembangkan usaha KSM.

Peran dosen dan mahasiswa fasilitator pendamping akan memfasilitasi terjalinnya kemitraan tersebut dengan mencari usaha-usaha/chaneling didesa dan diluar desa.

13.Membangun sinergitas antara pemerintah, masyarakat, dan swasta dalam rangka mengelola potensi dan meminimalisir permasalahan dalam pemberdayaan BUMDes.

Peran dosen dan mahasiswa fasilitator pendamping akan memfasilitasi dalam menjalin sinergitas tersebut khususnya menjalin komunikasi diantaranya.

\section{B. Bahan dan Peralatan}

Dalam pelaksanaan kegiatan ini, digunakan beberapa alat sebagai perlengkapan jalannya kegiatan atau mendukung kegiatan dalam mencapai hasil yang maksimal. Beberapa alat bahan yang digunakan yaitu: Laptop, Infokus/LCD, Spidol, Kertas Plano, Karton warna, dan Lakban kertas. 


\section{Indikator Keberhasilan}

Ukuran yang digunakan untuk mengetahui keberhasilan dari program ini adalah pengukuran tingkat kepuasan dan pemahaman masyarakat tentang pemberdayaan BUMDes, pahamnya pengurus BUMDes dalam pengelolaan keuangan, dilakukannya restrukturisasi pengurus BUMDes, terbentuk dan terlaksananya pelatihan kelompokkelompok usaha ekonomi kewirausahaan/KSM, serta terjalinnya sinergitas antara pemerintah, masyarakat, dan swasta dalam rangka mengelola potensi dan meminimalisir permasalahan dalam pemberdayaan BUMDes.

\section{Monitoring dan Evaluasi Kegiatan}

Monitoring dilakukan untuk mencatat perkembangan, memantau proses dan kemajuan pelaksanaan kegiatan secara terus-menerus, mengidentifikasi masalah dan penyimpangan yang muncul, merumuskan pemecahan masalah, dan membuat laporan kemajuan secara rutin dalam kurun waktu yang ditentukan. Kegiatan evaluasi dilakukan untuk mengkaji relevansi, efisiensi, efektivitas dan dampak suatu program sesuai dengan tujuan yang ingin dicapai. Untuk melakukan monitoring dan evaluasi pelaksanaan memerlukan data dan informasi yang tepat waktu, akurat, relevan dan lengkap. 
Monev dilakukan dimulai dari pelatihan mahasiswa fasilitator pendamping, sosialisasi, perencanaan, pelaksanaan dan keberlanjutan program. Ini digunakan untuk memperbaiki kualitas pelaksanaan dan penyesuaian terhadap perencanaan program.

Pelaporan hasil monitoring dan evaluasi dilakukan oleh semua pihak yang terlibat sebagai pelaku monev. Pelaporan hasil monev dilakukan secara teratur dan berkala serta disusun dalam bentuk laporan lengkap dan laporan populer yang sederhana, menarik, dan mudah dipahami.

Pelaksanaan monev dilakukan dalam waktu yang bersamaan, tergantung dari waktu pelaksanaan masing-masing program.

Bagian dari pelaksanaan Monev, terdiri atas 2 jenis, yaitu :

1. Monitoring Khusus, meliputi bagian kegiatan persiapan yang fokus kepada dosen dan mahasiswa fasilitator pendamping.

2. Monitoring Umum, meliputi bagian kegiatan proses \& output yang fokus kepada masyarakat.

Selain itu akan dilakukan monev internal yaitu monev yang dilakukan oleh pelaksana kegiatan, lembaga pemberi dana yaitu STISIP Muhammadiyah Rappang dan penerima manfaat/masyarakat. Prosedur monev internal ini dapat dilakukan dengan melakukan observasi langsung, wawancara, dan penyebaran cek list. 
Monev eksternal dilakukan secara independen, oleh organisasi lain. Monev eksternal ini dilakukan oleh pihak luar yang independen dan badan yang independen yang tidak secara langsung terlibat dalam pelaksanaan kegiatan. Pemantauan eksternal diharapkan dapat memberi pandangan yang lebih obyektif misalnya dari pihak kopertis/ristekdikti jika diperlukan.

\section{E. Keberlanjutan Dari Program Pengabdian Yang Dilaksanakan}

Setelah program selesai keberlanjutan program dapat terus berjalan karena metode yang dijalankan sejak awal dengan melibatkan warga sejak sosialisasi dan perencanaan dengan menumbuhkan nilai-nilai kemanusiaan dan kemasyarakatan diharapkan akan membuat masyarakat merasa memiliki terhadap program dan kelembagaan yang ada, sehingga masyarakat akan ikut dalam mengawasi pelaksanaan program dan menjaga keberlanjutan program ini berdasarkan program yang telah disusun dalam RPJMDes.

\section{F. Hambatan-Hambatan Yang Dihadapi Di Lapangan}

Hambatan-hambatan yang dihadapi dalam program pengabdian ini yaitu:

1. Pelaksanaan waktu yang singkat dalam menumbuhkan kesadaran masyarakat akan pentingnya berhimpun dalam kelompok- 
Halaman - 36

kelompok ekonomi kewirausahaan.

2. Menjalin kesepahaman diantara seluruh stakeholder pemberdayaan BUMDes. 


\section{BAB IV}

\section{PENUTUP}

\section{Kesimpulan dan Saran}

Kedepan sedikitnya ada empat hal yang perlu kita fikirkan bersama dalam pengelolaan BUMDes. pertama, mengenali dan menggali potensi masing-masing desa dan mencari cara untuk mengelola potensi tersebut. Kedua, mendorong aliran dana CSR oleh swasta untuk mendukung permodalan BUMDes. Ketiga, mendorong munculnya inisiasi dari pemerintah desa. Keempat, mendorong peningkatan partisipasi masyarakat secara nyata. Dengan melakukan sedikitnya empat hal tersebut diharapkan ke depan setiap desa mampu memiliki BUMDes yang bisa turut menopang perekonomian masyarakat desa. 


\section{DAFTAR PUSTAKA}

\section{Buku dan Jurnal}

Barokah, Hindun dkk. Cet 1 2015. Buku Indeks Pembangunan Desa 2014. Jakarta : Kementrian PPN/Bappenas dan BPS.

Chambers, Robert. 1992. Memahami Desa Secara Partisipatif. Yogyakarta : Kanisius dan Oxfam.

Direktorat PSD. 2015. Indeks Desa Membangun. Jakarta: Kemendesa, PDIT.

Hamidi, Hanibal (Ketua Tim Penyusun) dkk. Indeks Desa Membangun 2015. Jakarta: Kementerian Desa, Pembangunan Daerah Tertinggal dan Transmigrasi.

Isbandi. 2007. Perencanaan Partisipatoris Berbasis Aset Komunitas: dari Pemikiran Menuju Penerapan. Depok: FISIP UI Press .

Konsultan Manajemen Wilayah - VI P2KP II. 2004. Modul Pelatihan Pemetaan Swadaya dan Perencanaan Partisipatif Bagi Fasilitator. Palu.

Mardikanto, Totok dan Poerwoko Soebiato. 2015. Pemberdayaan Masyarakat Dalam Perspektif Kebijakan Publik. Bandung : Alfabeta

Akhmad, I., Mustanir, A., \& Ramadhan, M. R. (2018). Pengaruh Pemanfaatan Tekhnologi Informasi dan Pengawasan Keuangan Daerah Terhadap Kualitas Laporan Keuangan Kabupaten Enrekang. In Prosiding Konferensi Nasional Ke-7 Asosiasi Program Pascasarjana Perguruan Tinggi Muhammadiyah Aisyiyah (APPPTMA). Jilid 2. Sosial Politik dan Ekonomi (pp. 89-103). Retrieved from http:/ /asosiasipascaptm.or.id/index.php/publikasi/konferensiappptm-ke-7-meningkatkan-kualitas-dan-kuantitas-jurnal-ilmiah

Barisan, B., Ramadhan, M. R., \& Mustanir, A. (2017). Sidenreng Rappang Versus Masyarakat Ekonomi Asean. In The 2nd Journal of Government and Politics International Conference (Vol. II, pp. 258 262). Yogyakarta: Penerbit Program Pascasarjana Universitas Muhammadiyah Yogyakarta. Retrieved from http:/ /jksg.umy.ac.id/proceeding-2nd-jgp/

Damis Dadda, A., Mustanir, A., Nilwana, A., \& Ahmad, J. (2019). Pengaruh Kepemimpinan Lurah Perempuan Terhadap Stabilitas Kamtibmas Di Kelurahan Rappang Kabupaten Sidenreng Rappang. In Konferensi Nasional Ke-8 Asosiasi Program Pascasarjana Perguruan Tinggi Muhammadiyah Aisyiyah (APPPTMA) (pp. 378-383). Medan: Program Pascasarjana Universitas Muhammadiyah Yogyakarta. Retrieved from 
http:/ / asosiasipascaptm.or.id/index.php/publikasi/prosidingkonferensi-nasional-appptma-ke-8

Mustanir, Ahmad; Abadi, P. (2016). PARTISIPASI MASYARAKAT DALAM MUSYAWARAH RENCANA PEMBANGUNAN DI KELURAHAN KANYUARA KECAMATAN WATANG SIDENRENG KABUPATEN SIDENRENG RAPPANG. Jurnal Politik Profetik, 5(2), 247-261. Retrieved from http://journal.uinalauddin.ac.id/index.php/jpp/article/viewFile/4347/3986

Mustanir, Ahmad; Barisan, Barisan; Hamid, H. (2017). Participatory Rural Appraisal As The Participatory Planning Method Of Development Planning. In P. K. Nanang Haryono, Agie Nugroho Soegiono, Putu Aditya Ferdy Ariawantara (Ed.), Indonesian Association for Public Administration (IAPA) International Conference Towards Open Government: Finding the Whole Government Approach (pp. 77-84). Surabaya: The Faculty Of Social And Political Science Universitas Airlangga. Retrieved from http:/ / conference.unair.ac.id/index.php/IAPA/iapa2017

Mustanir, A. (2016). Perencanaan Mewujudkan Kehidupan Pemerintahan dan Sosial Yang Islami di Desa Tonrong Rijang Kabupaten Sidenreng Rappang. Prosiding Seminar Nasional, Reformasi Dan Inovasi Tata Kelola Pemerintahan, 289 - 307. Retrieved from https://www.researchgate.net/publication/330101808_Perencanaa n_Mewujudkan_Kehidupan_Pemerintahan_dan_Sosial_Yang_Isla mi_di_Desa_Tonrong_Rijang_Kabupaten_Sidenreng_Rappang

Mustanir, A., Abadi, P., \& Nasri, A. (2016). Participation of Ethnic Community Towani Tolotang in Deliberation of Development Plan. In International Conference on Ethics in Governance (ICONEG 2016) (Vol. 84, pp. 356 - 359). Makassar: Atlantis Press. https:// doi.org/10.2991/iconeg-16.2017.79

Mustanir, A., Ali, A., \& Yasin, A. (2018). Transect on Participatory Development Planning in Sidenreng Rappang Regency. In IOP Conference Series: Earth and Environmental Science. Maka.

Mustanir, A., \& Darmiah, D. (2016). IMPLEMENTASI KEBIJAKAN DANA DESA DAN PARTISIPASI MASYARAKAT DALAM PEMBANGUNAN DI DESA TETEAJI KECAMATAN TELLU LIMPOE KABUPATEN SIDENRENG RAPPANG. Jurnal Politik Profetik, 4(2), 225-238. Retrieved from http://journal.uinalauddin.ac.id/index.php/jpp/article/view/2749

Mustanir, A., \& Jaya, I. (2016a). PENGARUH KEPEMIMPINAN DAN BUDAYA POLITIK TERHADAP PERILAKU PEMILIH TOWANI 
TOLOTANG DI KECAMATAN MARITENGNGAE KABUPATEN SIDENRENG RAPPANG. Jurnal Politik Profetik, 4(1), 84-97. Retrieved from http://journal.uinalauddin.ac.id/index.php/jpp/article/view/2741\#

Mustanir, A., \& Jaya, I. (2016b). PENGARUH KEPEMIMPINAN DAN BUDAYA POLITIK TERHADAP PERILAKU PEMILIH TOWANI TOLOTANG DI KECAMATAN MARITENGNGAE KABUPATEN SIDENRENG RAPPANG. Jurnal Politik Profetik, 04(1), 84-97. Retrieved from http://journal.uinalauddin.ac.id/index.php/jpp/article/view/2741\#

Mustanir, A., \& Jusman. (2016a). IMPLEMENTASI KEBIJAKAN DAN EFEKTIVITAS PENGELOLAAN TERHADAP PENERIMAAN RETRIBUSI DI PASAR LANCIRANG KECAMATAN PITU RIAWA KABUPATEN SIDENRENG RAPPANG. Jurnal Ilmiah Akmen, 13(3), 542-558. Retrieved from https://e-jurnal.stienobelindonesia.ac.id/index.php/akmen/article/view/69

Mustanir, A., \& Jusman. (2016b). IMPLEMENTASI KEBIJAKAN DAN EFEKTIVITAS PENGELOLAAN TERHADAP PENERIMAAN RETRIBUSI DI PASAR LANCIRANG KECAMATAN PITU RIAWA KABUPATEN SIDENRENG RAPPANG. Jurnal Ilmiah Akmen.

Mustanir, A., Justira, N., Sellang, K., \& Muchtar, A. I. (2018). Democratic Model On Decision-Making At Deliberations Of Development Planning. International Conference on Government Leadership and Social Science (ICOGLASS). Demanding Governance Accountability and Promoting Democratic Leadership for Public Welfare Achievement, 110 $115 . \quad$ Retrieved from https://www.researchgate.net/publication/330090538_Democratic _Model_On_Decision-

Making_At_Deliberations_Of_Development_Planning

Mustanir, A., \& Lubis, S. (2017a). Participatory Rural Appraisal in Deliberations of Development Planning. International Conference On Democracy, Accountability, and Governance (ICODAG 2017) (Vol. 163). https://doi.org/10.2991/icodag-17.2017.60.

Mustanir, A., \& Lubis, S. (2017b). Participatory Rural Appraisal in Deliberations of Development Planning. In International Conference On Democracy, Accountability, and Governance (ICODAG 2017) (Vol. 163, pp. 316-319). Pekanbaru: Atlantis Press. https://doi.org/10.2991/icodag-17.2017.60.

Mustanir, A., \& Razak, M. R. R. (2017). Nilai Sosial Budaya Pada Partisipasi Masyarakat Etnik Towani Tolotang Dalam Musyawarah 
Rencana Pembangunan. In Prosiding Konferensi Nasional Ke-6 Asosiasi Program Pascasarjana Perguruan Tinggi Muhammadiyah Aisyiyah (APPPTMA) (pp. 1-7). Pare Pare: Program Pascasarjana Universitas Muhammadiyah Yogyakarta. Retrieved from http:/ / asosiasipascaptm.or.id/index.php/publikasi/prosidingkonferensi-nasional-appptma-ke-6

Mustanir, A., \& Rusdi. Muhammad. (2019). Participatory Rural Appraisal (PRA) Sebagai Sarana Dakwah Muhammadiyah Pada Perencanaan Pembangunan Di Kabupaten Sidenreng Rappang. In Konferensi Nasional Ke-8 Asosiasi Program Pascasarjana Perguruan Tinggi Muhammadiyah Aisyiyah (APPPTMA) (pp. 378-383). Medan: Penerbit Program Pascasarjana Universitas Muhammadiyah Yogyakarta. Retrieved from http:/ / asosiasipascaptm.or.id/index.php/publikasi/prosidingkonferensi-nasional-appptma-ke-8

Mustanir, A., \& Rusdi, M. (2019a). Participatory Rural Appraisal (PRA) Sebagai Sarana Dakwah Muhammadiyah Pada Perencanaan Pembangunan di Kabupaten Sidenreng Rappang. Prosiding Konferensi Nasional Ke-8 Asosiasi Program Pascasarjana Perguruan Tinggi Muhammadiyah Aisyiyah (APPPTMA). Medan. Retrieved from http:/ / asosiasipascaptm.or.id/index.php/publikasi/prosidingkonferensi-nasional-appptma-ke-8

Mustanir, A., \& Rusdi, M. (2019b). Participatory Rural Appraisal (PRA) Sebagai Sarana Dakwah Muhammadiyah Pada Perencanaan Pembangunan di Kabupaten Sidenreng Rappang. Prosiding Konferensi Nasional Ke-8 Asosiasi Program Pascasarjana Perguruan Tinggi Muhammadiyah Aisyiyah (APPPTMA).

Mustanir, A., \& Yasin, A. (2018). Community Participation in Transect on Development Planning. Jurnal Ilmiah Ilmu Administrasi Publik: Jurnal Pemikiran Dan Penelitian Administrasi Publik (JIAP), 8(2), 137-146. https:// doi.org/https:// doi.org/10.26858/jiap.v8i2.7994

Mustanir, A., Yasin, A., Irwan, I., \& Rusdi, M. (2018). Potret Irisan Bumi Desa Tonrong Rijang Dalam Transect Pada Perencanaan Pembangunan Partisipatif. MODERAT: Jurnal Ilmiah Ilmu Pemerintahan, 4(4), 1-14. Retrieved from https://jurnal.unigal.ac.id/index.php/moderat/article/view/1775

Razak, M. R. R., Dahong, M., Ahmad, J., Dema, H., \& Mustanir, A. (2018). The Effect of Siri's Marriage on Government Administration. International Journal of Sciences: Basic and Applied Research (IJSBAR), 42(3),

171-184.

Retrieved

from 
http:/ /gssrr.org/index.php?journal=JournalOfBasicAndApplied\& page $=$ article\&op $=$ view $\&$ path $\% 5 B \% 5 D=9484$

Ridwan, Zulkarnain. Urgensi Badan Usaha Milik Desa (Bumdes) Dalam Pembangunan Perekonomian. Fiat Justicia Jurnal Ilmu Hukum Volume 8 no 3 Juli-September 2014. ISSN 1978-5186

Subekti, Tia. Arinda, Agies. Pengelolaan BUMDes melalui Good Governance Studi Kasus: BUMDes Tirta Mandiri Desa Ponggok Klaten Jawa Tengah. Program Studi Ilmu Pemerintahan FISIP Universitas Brawijaya Malang

Suharto, Edi. 2006. Membangun Masyarakat Memberdayakan Rakyat. Bandung : Refika Aditama.

Sumpeno, Wahyudin. Perencanaan Desa Terpadu (Panduan Perencanaan Pembangunan Berbasis Masyarakat). Jakarta : CRS Indonesia.

Supriatna, Tjahya. 2000. Strategi Pembangunan dan Kemiskinan. Jakarta : Rineka Cipta.

Sutoro, Eko dkk. Cetakan Pertama April 2016. Dana Desa Untuk Desa Membangun Indonesia (Tanya Jawab Seputar Dana Desa). Kementerian Desa, Pembangunan Daerah Tertinggal, dan Transmigrasi Republik Indonesia.

Tim Penyusun Kementrian Desa, PDT dan Transmigrasi. Cet 1 Juni 2015. Tanya Jawab Seputar Undang-Undang Desa. Jakarta : Kementrian Desa, PDT dan Transmigrasi.

\section{Undang-Undang dan Peraturan Lainnya}

PP Nomor 72 Tahun 2005 tentang Desa

PP 22 Tahun 2015 Perubahan PP 60 Dana Desa

PP 43 Tahun 2014 Peraturan Pelaksanaan UU Desa

PP 47 Tahun 2015 - Perubahan PP No 43 Tahun 2014 Tentang Peraturan Pelaksanaan UU No 06 Tahun 2014

PP 60 Tahun 2014 tentang Dana Desa dari APBN

Peraturan Menteri dalam Negeri Nomor 66 Tahun 2007 tentang Perencanaan Pembangunan Desa

Peraturan Menteri Dalam Negeri nomor 39 tahun 2010 tentang Badan Usaha Milik Desa

Permendagri No. 113-2014 Pedoman Pengelolaan Keuangan Desa 
Permendagri No. 114-2014 Pembangunan Desa

Permendesa Nomor 4 tahun 2015 tentang 2015 tentang Pendirian Pengurusan Dan Pengeloelaan Dan Pembubaran Badan Usaha Milik Desa

Permendesa No 3-2015 Pendampingan Desa

Undang-Undang Nomor 6 Tahun 2014 tentang Desa

Undang-Undang Nomor 23 tahun 2014 tentang Pemerintahan Daerah 


\section{LAMPIRAN-LAMPIRAN}

1. Foto Lokasi Pengabdian via google map

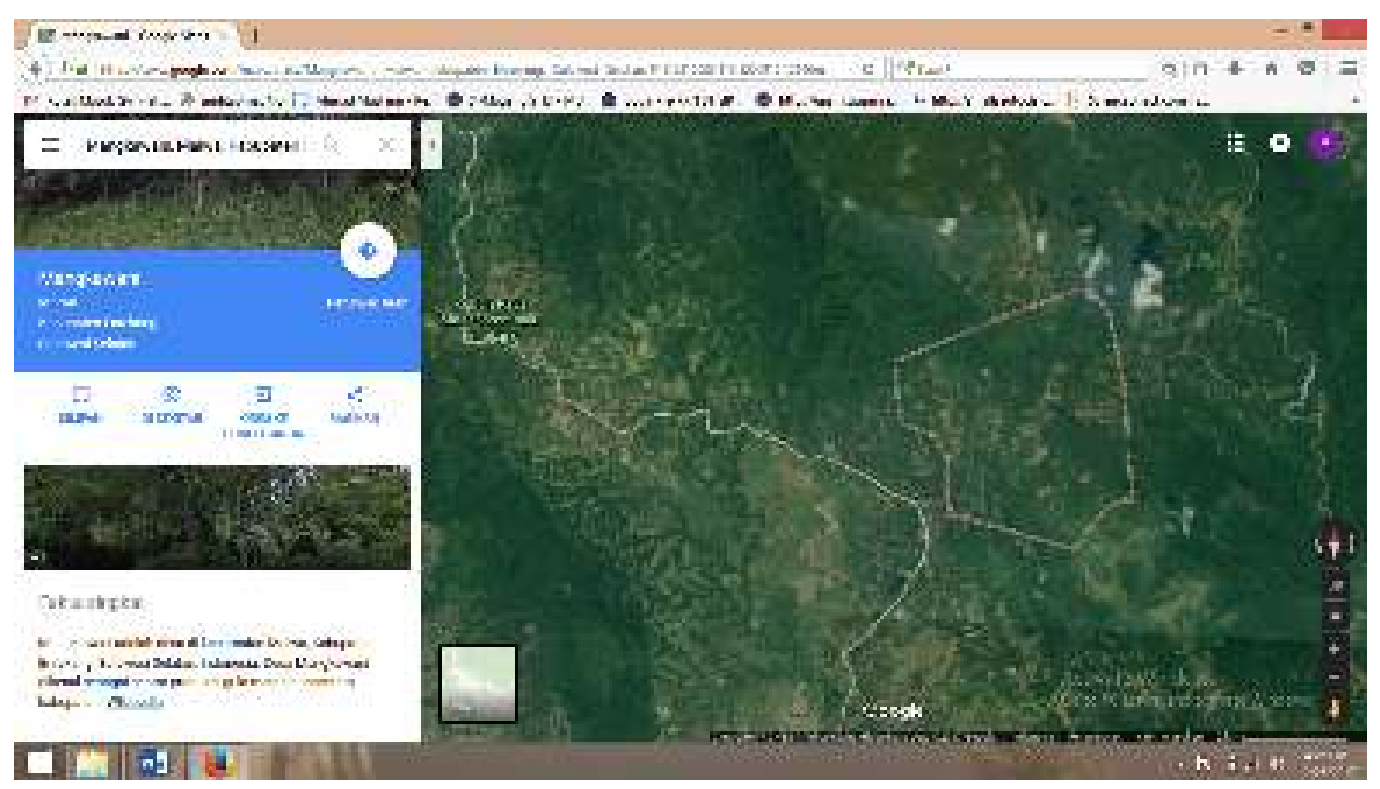

